\title{
Türkiye'de Yargı ile Siyaset İlişkisinin Kuvvetler Ayrılığı Perspektifinden Analizi
}

\author{
Mustafa ULUÇAKAR* ${ }^{*}$ Mehmet Fatih ÇINAR**
}

\begin{abstract}
Öz
Bu çalışmanın amacı Türkiye'de siyaset yargı ilişkisini, bu ilişki çerçevesinde yargı bağımsızlığı ve tarafsızlığı kavramlarının nasıl yapılandığını kuvvetler ayrılığı perspektifinden analiz etmektedir. Günümüz Türkiye'sinde yargı ile siyaset arasındaki ayrımın giderek daha fazla silikleștiğine dair iddialar artmaktadır. Bu iddialar yargı siyaset ilişkinin olması gereken noktadan saptığı noktasında yoğunlaşmakta ve kuvvetler ayrılığı ilkesinin hukuksal değerinin ulusal ve uluslararası yargı bağımsızlığı düzenlemeleri açısından incelenmesini gerektirmektedir. Çalışma, yöntem olarak nitel ve betimleyici bir araştırmadır. Çalışma verisi ikincil kaynaklar-literatür taraması (Anayasa Mahkemesi Kararları, Resmî Gazete arşivleri, ilgili yasal mevzuat, ilgili literatür, gazete arşivleri, konuyla ilgili araştırmalarda yer alan istatistiksel veriler) yoluyla elde edilmiş ve analitik bir değerlendirmeye tabi tutulmuştur.
\end{abstract}

Anahtar Kelimeler: Kuvvetler Ayrılığı, Hukuk, Anayasa, Yürütme-Siyaset, Yargı Bağımsızlığı

\section{Analysis from the Perspective of the Separation of Powers Between Judiciary and Politics in Turkey}

\begin{abstract}
The aim of this study is to analyze the relationship between the politics and the judiciary as well as how the concept of judicial independence and impartiality are shaped within the framework of this relationship from the perspective of separation of power in Turkey. Today the allegations related to the distinction between politics and the judiciary are becoming more indistinct in Turkey are increasing. These claims focus on the point that relations between the politics and the judiciary deviate from the point at which they should be and require the legal values of the principle of separation of powers to be examined in terms of national and international judicial regulations related to the judicial independence. The study is a qualitative and descriptive research. The study data were obtained through the analysis of secondary sources-literature scan (Constitutional Court Decisions, Official Gazette archives, relevant legislation, related literature, newspaper
\end{abstract}

Özgün Araştırma Makalesi (Original Research Article)

Geliş/Received: 02.04.2019

Kabul/Accepted: 18.11 .2019

DOI: https://dx.doi.org/10.17336/igusbd.548020

* Dr. Öğr. Üyesi, İstanbul Geliş̧im Üniversitesi, İISBF, Siyaset Bilimi ve Kamu Yönetimi, İstanbul,

Türkiye, E-posta: mulucakar@gelisim.edu.tr ORCID ID https://orcid.org/0000-0002-1607-1802

** Dr. Öğr. Üyesi, İstinye Üniversitesi, Adalet Programı, İstanbul, Türkiye,

E-posta: fatih.cinar@istinye.edu.tr ORCID ID https://orcid.org/0000-0002-1849-7161 
archives, statistical data of the relevant researches) and subjected to an analytical evaluation.

Keywords: Separation of Powers, Law, Constitution, Executive-Politics, Judicial Independence

\section{Giriş}

Türkiye'de devletin yönetsel gücünü elinde bulunduran yürütme kuvvetinin, bir başka ifadeyle, siyaset makamının yargıyla denetlenebileceğine dair inanışlar giderek azalmaktadır. $\mathrm{Bu}$ bağlamda, siyasetin yargıyı etkileyebilme potansiyeli ve yargı bağımsızlığı ile yargı siyaset ilişkisi tartıșmaları sürekli bir biçimde Türkiye'nin gündemini meșgul etmektedir.

Türk kamuoyunun önemli bir bölümü siyasi etkilerle yargının yönlendirilmeye çalışıldığından şikâyet etmektedir. Buna karșın, Hâkim ve Savcılar Kurulunun (HSK) yasal başkanı ve siyasi gücün yargı örgütündeki en üst düzey temsilcisi olan Adalet Bakanları ise esasen yargı mensuplarının bu türden şikâyetlerinin siyasi nitelikte şikâyetler olduğunu ve hâkimlerin kararları ile konuşması gerektiğini ileri sürmektedir. $\mathrm{Bu}$ tartışmalar, aslında hukuk eğitiminden başlayan ve yargı kararlarının bütünüyle uygulanmasına kadar uzanan ve çok geniş boyutları olan yargının bağımsızlığı ile etkinliği alanını ilgilendirmektedir. Siyasetin yargıya, yargının da siyasete karıșmaması ise, bu geniş sorun alanının daha dar bir kapsam ile sunulması olarak karşımıza çıkmakta ve bu tartışmalara konu olan iddialarda yargı siyaset ilişkisinin olması gereken noktadan saptığı hususu öne çıkarılmaktadır.

Çalışma, yöntem olarak nitel ve betimleyici bir araştırmadır. Çalışma verisi ikincil kaynaklar-literatür taraması (Anayasa Mahkemesi Kararları, Resmî Gazete arşivleri, ilgili yasal mevzuat, ilgili literatür, gazete arşivleri, konuyla ilgili araştırmalarda yer alan istatistiksel veriler) yoluyla elde edilmiş ve analitik bir değerlendirmeye tabi tutulmuștur. Türkiye'de yargı ile siyaset ilişkisinin kuvvetler ayrılığı perspektifinden analizini amaçlayan bu çalışmanın, kuvvetler ayrılığı ilkesinin hukuksal değerinin ulusal ve uluslararası yargı bağımsızlığı düzenlemeleri açısından daha iyi anlaşılmasına imkân vermenin yanı sıra ilgili literatüre katkı sunacağı düşünülmektedir. Keza çalıșmanın temellerini oluşturan kavramların genel kabul gören tanımlarının ve çalışma konusunun üzerine bina edildiği kuramsal çerçevenin başlangıçta hatırlatılmasının konunun daha iyi anlaşılmasına katkı sağlayacağı değerlendirilmektedir.

\section{Kavramsal ve Kuramsal Çerçeve}

Duverger'e göre siyasal rejim: "geniş anlamıyla, belirli bir sosyal grupta, iktidar ile yönetilenler arasındaki ayrımın aldığı biçime; dar anlamıyla ise, sadece ulusun yönetim yapısına" karşılık gelmektedir (Duverger, 1995). İktidar kavramının sözlük anlamı ise bir işi yapabilme, başkalarının davranışlarını kontrol edebilme denetleyebilme, yönetme gücü, devlet yönetimini elinde bulundurma ve devlet gücünü kullanma yetkisi olarak tanımlanmıştır (TDK, 2019). İktidar, aile, okul, siyasi parti, sendikada vb. yaşamın her alanında görülebilir. İktidar biçiminin en üst düzeyi ise siyasi iktidardır. Zira siyasi iktidarın tüm devlet ve toplum üzerinde denetleme yetkisi vardır. Alman Hukukçu Georg Jellinek'in teorisine göre, devleti oluşturan unsurlar; 'ülke', 'nüfus' ve 'egemenlik' şeklinde karşımıza çıkmakta ve siyasal rejimler, egemenliğin kaynağına (monark/oligark/birey) ve kullanım tarzına bağlı olarak monarşi, oligarşi ve demokrasi şeklinde tasnif edilmektedir (Doehring, 2002). Fransız yazar Montesquieu (1963)'nün kuvvetler ayrılığı 
yaklaşımında devletin fonksiyonları 'yasama', 'yürütme' ve 'yargı' olarak tasnif edilmektedir.

Devletin fonksiyonlarını elinde bulunduran ve egemenlik hakkını kullanan organların hukuka ve kamu vicdanına uygun olarak bu yetkiye sahip olmaları meşruiyet kavramı ile açıklanmaktadır. Bir iktidarın meșru olması, hukuki dayanağının olması ve yönetilenler tarafindan yasal olarak görülmesi anlamına gelmektedir (Gözler, 2011). Diğer bir deyişle, meşruiyetin iki yönü vardır: Birincisi yasalara, hukuka uygunluk; ikincisi ise kamuoyunun çoğunluğunca haklı addedilmektir. Meşru olmayan iktidar ise kaba güçten bașka bir șey değildir. Nitekim 'demokrasi' kavramı da, Anayasa Mahkemesinin 26.06.2014 tarihli ve Başvuru No: 2014/256 sayıll, Genel Kurul Kararında "temel hak ve özgürlüklerin en geniş şekilde sağlanıp güvence altına alındığı, farklı inanç, düşünce ve hayat tarzlarını barıș içinde bir arada tutma anlayıșı" (Resmî Gazete, sayı: 29051) olarak tanımlanmaktadır.

Devletin egemenlik gücü, yönetme gücünü kullanabilmesi anlamına gelmektedir. Devletlerin egemenlik gücünün hem ulusal hem de uluslararası boyutu bulunmaktadır. Ulusal egemenlikten kast edilen, devletin yasama, yürütme yargı güçlerini kendi sınırları içerisinde kullanabilmesidir. Uluslararası egemenlikten de, herhangi bir devletin başka bir devlete bağımlı olmadan uluslararası alanda varlık gösterebilmesidir. Demokratik devletlerde egemenlik, halka ait ve halk adına kullanılan egemenliktir. Diğer bir deyişle egemenlik halk için, halk adına, halk tarafından yürütülür. Kuvvetler ayrılığı ilkesi ise yetkilerin kötüye kullanılmamasını sağmaya yönelik -denetleyici ve dengeleyici- bir ilkedir.

\section{Siyasi İktidarın Kaynağı}

Egemenlik gücünü kullanan siyasi iktidar meşru olmak zorundadır. İktidarın meşruluğu problemi devlet kavramı konusunun önemli bir sorun alanını teşkil etmektedir. Nitekim iktidarın meşruiyetinin kaynağı tarihsel süreçte farklı temellere dayandırılmıştır. Diğer bir deyişle, siyasi iktidarlar, çoğu zaman, kendi güçlerini meşruluk kavramı üzerinden kurabilmek ve tahkim edebilmek için gerekçeler (teolojik, metafizik, felsefi ve hukuki) aramışlardır.

Buna ilişkin görüşleri aşağıdaki şekilde özetlemek mümkündür: Eski Yunan dönemi temsilcilerinden Platon ve Aristoteles, iktidarın kaynağını insanın doğal yapısında bulurlar (Aristoteles, 1975; Platon, 2005). Zira devletin görevi bireylerin ihtiyaçlarını gidermek, onların güvenliğini sağlamak ve erdemli bireyler olarak yetişmelerini sağlamaktır. Eğer bir iktidar bu görevleri gerçekleștirebiliyorsa o iktidar meșru bir iktidardır. Orta Çağ felsefesinde ise iktidar kaynağını Tanrı'da bulur. Yani, iktidar, bir anlamda, O'nun dünyadaki temsilcisidir. Meşruluk Tanrı'nın iktidara gösterdiği amaca uygunlukla ilgilidir. Modern anlayışın temellerini atan düşünürlerin başında gelen Thomas Hobbes, John Locke ve Jean-Jacques Rousseau iktidarın kaynağını toplumsal sözleşmede bulurlar. İktidar insanların kendi rızalarıyla teslim ettiği hak ve özgürlüklerin korumak ve adaleti tesis etmekle yükümlü gücün temsilcisidir. İktidarın meşruluğu bireylerin çıkarlarının toplumun genel istencine uygun olarak korunması ile ölçülür (Hobbes, 2007; Locke, 2002; Arsel, 1968). Nitekim Kapani'ye göre de Rönesans ve Reformun özgür düşüncenin kapılarını aralaması iktidarın kaynağına ilişkin anlayışı değiștirmiştir:

Siyasal iktidarın meşruluk temeli önceleri gökyüzünde, Tanrıda ve kutsal kaynaklarda aranmıştır. Bu kabulden yola çıkarak kralların tanrısal varlıklar oldukları kabul edilmiştir. Teolojik meşruluk yumuşak bir geçiş ile bütün iktidarların Tanrı'dan geldiği (Omnis potestas a Deo) anlayışına doğru evirilmiştir. Bu çığır açan yaklaşım kralın kişiliğinin Tanrısal olmaktan çıkması anlamına gelmekteydi. Ancak iktidarlar yine de bir 
'ilahi hak' fiksiyonu üzerine dayanmaktaydı. Rönesans ve Reformun özgür düşüncenin kapılarını aralaması, Fransız Devriminin yeni bir anlayışı egemen kılmasıyla birlikte iktidarın kaynağı 'Milli Egemenlik' ve 'Birey' temelli olarak demokratik anlayışa devrimsel bir geçiş yaptı (Kapani, 2007).

\section{Kuvvetler Ayrılığı İlkesi}

Modern siyaset biliminin kurucularından ve aydınlanmanın öncülerinden kabul edilen Montesquieu, 1731-1748 yılları arasında hiç ara vermeden, Brede Şatosunda Kanunların Ruhu Üzerine (De L'esprit des Lois) adlı eseri üzerinde çalışmış ve çalışmasının İngiltere'nin Anayasası başlıklı bölümde kuvvetler ayrılığına ilişkin görüşlerine yer vermiştir. Montesquieu'nün politik öğretisi dengeye, farklı bir deyişle, iktidarın iktidar ile sınırlandırılması ilkesine dayanmaktadır. Yönetimde bulunan iktidarın devlet gücünü kendi çıkarları istikametinde kullanmasını engellemenin tek yolu iktidarın bir diğer iktidar ile sınırlandırılmasıdır. Bunun temin için devleti ortaya çıkaran kuvvetler birbirinden ayrılmalı ve farklı iktidar odaklarına verilmelidir. Montesquieu bu bağlamda, bir devlette yasama, yürütme ve yargı fonksiyonları olmak üzere üç kuvvet bulunduğunu kabul etmektedir. Montesquieu'ye göre siyasal özgürlüğün ve güvenliğin sağlanması da ancak, iktidarlar dengesi ile kurulabilir. Yasama gücü ile yasaları baskı yoluyla yürürlüğe koyan güç ayni ise o yerde özgürlük yoktur. Keza yasama ile yargı birleşmişse, kişinin canı da özgürlügü de güvence altında değildir. Zira aynı zamanda yasa koyucu durumunda olan yargıçlar keyfi kararlar verebilir. Yargıçların yürütme iktidarına da sahip olması ise onları zorba yapar (Montesquieu, 1963).

John Locke ve Montesquieu olmak üzere aydınlanma çağının düşünürleri tarafından geliştirilen kuvvetler ayrilığg ilkesi tarihsel süreç içerisinden metodolojik olarak doğrulanmıştır. Kuvvetler ayrılığı ilkesi günümüzde anayasalara ve hatta uluslararası örgütlerin teşkilatlanmalarına yön veren bir ilke âdeta bir kutup yıldızı halini almıştır. Zira kuvvetlerin tek elde toplandığı dönemlerin acı tecrübeleri halen toplumsal hafızalarda canlıdır. Bir devlette yasama ve yürütme erkleri tek bir elde toplandığı takdirde zaman içinde özgürlük ve demokrasinin giderek zayıfladığı görülmektedir. Hatta yargının, yasama ve yürütmeden ayrılmadığı hallerde, özgürlük ve demokrasiden söz edilemeyeceği açıktır. Basitleştirerek açıklamak gerekirse; kuvvetler ayrılığının işleyişi şu şekildedir: Yasama organı, diğer kuvvetlerin uygulamalarına temel olacak kararları ve/veya politikaları bir başka ifadeyle, mevzuatı yaratır. Yürütme organı ise, devletin idari aygıtları aracılığıyla bu mevzuatı uygular. Yargl; fonksiyonu yasamadan, yürütmeden ve idari/askeri bürokrasiden olabildiğince bağımsız ve tarafsız şekilde hukukun ne olduğunu söyler (Çınar, 2017).

Kuvvetler ayrılığı konsepti, özü itibariyle, Locke'un iktidarın başka bir iktidarla sınırlanmadığı sürece demokrasinin gelişmeyeceğini varsayımı üzerine bina edilmiştir. Ancak Locke'un kuvvetler ayrılığı yaklaşımında yargı yürütmeden bütünüyle ayrı bir güç olarak görülmemektedir (Locke, 2002). Locke'un varsayımının günümüzde ne ölçüde geçerli olduğu sorusu, kuvvetler ayrllı̆̆ prensibini ortaya çıkaran tarihsel ve toplumsal koşullara ve bu koşulların yargı bağımsızlığı açısından nasıl bir evrim geçirdiğine bakılarak yanıtlanabilir. Esasen bu konseptin 18'nci yüzyıl monarşilerinin dayanağını teşkil eden 'iktidarın bölünmezliği' düşüncesine karşı, burjuva iktidarlarına yer açabilmek için geliștirildiğini söylemek yanlış olmayacaktır.

Montesquieu ise, Locke'un düşüncesini 18. yüzyll İngiltere'de da var olan siyasal yapısını gözlemek suretiyle geliştirmiştir. O'na göre hükümetler üçe ayrılır: saltanatlar, istibdatlar ve cumhuriyetler. Saltanatlar şahısların yerleşmiş kanunlar doğrultusunda idaresi anlamına gelir. İstibdatlar ise, şahısların herhangi bir kanun ve/veya kurala bağlı olmaksızın sadece, kendi istek ve arzularına göre (keyfi) idaresidir. Hürriyetlerin tam 
manasıyla geliştirilmesi için saltanat idaresinde bulunan kuvvetlerin ortadan kaldırılması gerekir. Saltanat hükümetlerinde ruhban sınıfının kuvveti ne kadar faydalı ise cumhuriyette ruhban sınıfı o kadar tehlikelidir. Montesquieu (1963)'ya göre müstebit hükümetler öyle korkunç kötülükler eder ki, bu kötülükleri önleyen bir kötülük bile, bir iyilik halini alır. Cumhuriyetlerde idare tümüyle milletin elinde olursa bu siyasal rejim demokrasi, bir kısmının elinde olursa ise aristokrasi adını almaktadır. Diğer yönetim modellerine ilişkin eleştirilerine bakıldığında Montesquieu'nün fazilet ile özdeşleştirdiği cumhuriyet yönetimini daha ön plana çıkardığını söylemek hatalı olmayacaktır.

Hiç kuşku yoktur ki, Amerikan ve Fransız anayasacılık hareketleri Montesquieu'nün düşüncelerinden esinlenmiştir. Anayasal demokrasilerin güç kazanmasıyla birlikte yetkiler krallardan alınıp yasama güçleri parlamentolara, yürütme güçleri ise halkın seçtiği hükümetlere bırakılmaya bașlanmıștır. Kuvvetler ayrılığı ilkesi ilk uygulama zeminini 1787 tarihli Amerika Birleșik Devletleri (ABD) Anayasası ile bulmuştur (ABD Anayasası, 1787). Alexander Hamilton, yargının, yasama ve yürütmeden ayrılmasını, tam bir yargı bağımsızlığını anayasanın temeli olarak tanımlamaktadır. Bunlar olmadığı takdirde tüm hak ve özgürlüklerin etkisizleșeceğini vurgulamaktadır (Hamilton, 1788).

Amerika'nın kurucu iradesini temsil eden Q. Madison, A. Hamilton, J. Jay gibi anayasa yapıcılar, siyasi denge ve kontrol (checks and balances) mekanizmalarını özgürlüklerin yaşamsal garantileri olarak görmektedirler. Bu mekanizmanın temelinde ise yargı bağımsızlığı ve anayasa yargısını olduğu belirtilmektedirler (Eleches, Porta, Shleifer, Silanes, 2004). Fransa, Amerika'da cereyan eden Anayasacılık hareketinden etkilenmiş ve İnsan ve Yurttaş Hakları Bildirgesi'nde "Hakların güven altına alınmadığı, kuvvetler ayrılığının belirlenmediği bir toplumda anayasa yoktur" (İnsan ve Yurttaş Hakları Bildirgesi) ifadesi yer almıştır. Kuvvetler ayrılığı ilkesinin Fransız yorumu ise biraz farklılaşmıştır. Fransız Devrimi döneminde, eski rejimde de uygulandığı gibi, idareyi rutin mahkemeler yerine, özel bir yargı düzeni yoluyla denetleme fikri hâkimdir. Bu düzen, daha sonra Kıta Avrupa'sında yargısal bir tercih halini almıștır (Pacteau, 1997).

Kuvvetler ayrılığı fikri, bir anlamda, devlet-toplum karşıtlığı zemininde kurulmuş ve bu karşıtlıkla yargı, tarafsız bir konuma yerleştirilmiştir. Yargının hem diğer devlet organlarına hem de vatandaşlara, siyasal oluşumlara, sivil toplum örgütlerine ve medyaya karşı tarafsızlığı sağlanmaya çalıșılmıştır. Bu suretle yargının, yargı dıșı etkilere maruz kalmaması amaçlanmıştır. Bununla birlikte, gelişmiş devletlerin anayasal sistemlerinde dahi idealize edildiği seviyede bir kuvvetler ayrılığının gerçekleștirilebildiğini söylemek oldukça güçtür. Bu nedenle her uygulama modeli çeşitli yönlerden eleştirilebilmektedir. Bu eleștiriler arasında, yürütme gücünün sınırlı bir devlet fonksiyonu kullanan organ olarak kalmadığı ve yasamaya tahsis edilmiş alanı adım adım işgal ettiği tespiti öne çıkmaktadır. Ulusal ve uluslararası politikaları belirlemede idari bürokrasinin yanı sıra adli bürokrasinin de söz hakkı olması gerektiği yönündeki beklentiler tartışma konuları arasında yer almaktadır.

Günümüzde devletin yasama ile yürütme ve karar alma ile uygulama fonksiyonları arasındaki ayrımlar günümüzde gittikçe silikleşmiş olsa da yargısal kurumların bağımsızlığı, demokratik hukuk devletinin evrensel ve vazgeçilmez bir değeri olarak kabul görmektedir. Yargı, kuvvetler ayrılığı ilkesini benimsemeyen devlet modellerinde dahi, her zaman tarafsız ve bağımsız bir şekilde konumlandırılmaya çalışılmaktadır (Çınar, 2018). İzleyen bölümde yargı ve siyaset ilişkileri ele alınmaktadır.

\section{Yargı Siyaset İlişkileri}

Kuvvetler ayrılığı ilkesi gereği birbirlerinden bağımsızlaşması öngörülen siyaset ve yargının, tam anlamıyla hiçbir zaman birbirinden ayrı olamadığı bir gerçektir. Aslında 
bu, Nietzsche'nin 'iktidar olma istenci' kavramlaştırmasındakine benzer biçimde iktidarlar, çoğu zaman, ayak bağı olarak gördükleri yargıyı denetlemek istemişlerdir. Buna karşın, yargı da siyasetin gem vurma eğilimlerine karşı duruş gösterme tutumu içinde olmuştur. Ancak, siyaset ve yargı arasında biteviye bir çatışma yerine, iktidar seçkinlerinin, çoğu kez, siyaseti ve yargıyı da içine alan ve birbirini tamamlayan bir ilişki biçimini tercih etmişlerdir. Yargının siyasallaştığı yönündeki iddialar, bazen de yargıçların yaptıklarına ilişkin deneye dayalı bir gözlemlerden ziyade, ne yapmaları gerektiği konusunda bireysel temennileri yansıtmaktadır. Bazı durumlarda, siyaseten üstesinden gelinemeyen ya da siyaseten ele alınmak istenmeyen işler yargiya havale edilmiştir. Bu konuların yargı yoluyla üstesinden gelinmeye çalışılmasının nedeni; bazen meșruluk bazen de muhtelif hukuksal risklerden kaçınmak kaygısından kaynaklanmıştır.

Yargının siyasallaşması iki ciddi olumsuzluğa sebebiyet verebilir. Birincisi, yargının siyasallaşmak suretiyle güvenilirliğini yitirmesi sorunu, ikincisi ise 'siyasetin yargısallaşması' sorunudur. Yargı, her iki durumda da, kuvvetler ayrılığı gereği kendisinden beklenen 'siyasal iktidarı denetlemek suretiyle özgürlükleri koruma' işlevini yerine getiremez hale gelecek ve fonksiyonel meşruiyet krizi ortaya çıkacaktır. Yargının fonksiyon kaybı, siyasetin kendi dinamiklerinden uzaklaștırılmasına ve yargısal yöntemlerle siyaset zemininin demokratik muhalefet olanağından yoksun bırakılmasına yol açacaktır. Siyasal alanın sınırlarının ve aktörlerinin yargısal güç ve işlevine haiz yürütme iktidarı tarafından belirlendiği, yargının kararlarını vermeden önce siyaset kurumundan icazet alır hale geldiği bir ortamda da 'siyasetin meşruiyeti' ve tüm kurumların 'siyasete bağımlılı̆̆ı' sorunu ortaya çıkacaktır.

Seçimle hem hükümeti elde eden hem de parlamento çoğunluğuna sahip olan siyasi partiler, yürütme ile yasama güçlerini birlikte kullanabilecek güce erișmekte, demokrasi kültürünün yeterince gelişmediği, medya ve kamuoyu denetiminin etkin olmadığı rejimlerde, iktidarlar -bazen de farkında bile olmadan- sahip oldukları iktidar gücünü hukuk dışı ve kötüye kullanma hatasına düșebilmektedirler. Bu tip otoriter iktidarlar hukuk devleti ilkesinin zayıflamasına ve hak ve hürriyetlerin ihlal edilmesine neden olmaktadır. Kontrolsüz bir hale gelen mutlak iktidarların önündeki sınırlandırıcı tek iktidar odağı olarak yargı gücü kalmaktadır. Yargı gücünün, yürütme ve yasama kuvvetleri karşısında gerçek anlamda bağımsız olmaması ise, işlevini gerektiği gibi yerine getirememesine, bunun sonucunda hukuki güvenliğin yok olmasına ve hak ve hürriyetlerin demokrasi ilkelerine aykırı olarak kısıtlanmasına yol açmaktadır (İșten, 2014). İzleyen bölümde Türkiye'de yargı siyaset ilişkileri incelenmektedir.

\section{Türkiye'de Yargı Siyaset İlişkileri}

Osmanlı Devleti'nde Tanzimat Dönemi ile bașlayan yargıyı yürütmeden ayırma çabaları adli yönden yapılan yeniliklerin bir boyutunu oluşturmaktadır. Divan-ı Ahkâm-ı Adliye'nin kurulması ile süreç somutlaşmıștır. Bu kurum Yargıtay'ın ilk nüvesini oluşturmuştur. 1868'de Padişah Abdülaziz'in iradesi ile kurulmuş ve amacının "kişilerin hakları ve güvenlikleri açısından çok önemli olan hukuk işlerinin mülki işlerden ve yürütme ile görevli hükümetten ayrı bir düzene kavuşturulması" olduğu belirtilmiștir (Karahanoğulları, 2005). Hemen peşinden Danıştay'ın temelini oluşturan Şuray-ı Devlet'in de kurulması ile Osmanlı, özel olarak Fransa, genel olarak Avrupa modeli bir yargı teşkilatı oluşturma çabasına girişmiştir.

Türkiye'nin anayasacıllk hareketlerinin 1808 Senedi İttifak (Magna Carta Libertatum benzeri) uzlaşı belgesi ile başladığı genel kabul görmektedir (Aslan, 2013); Mumcu ve Üçok, 1991). Türkiye'nin demokratikleşmesi ve buna paralel olarak kuvvetler ayrılığı ilkesinin etkin olarak uygulanması doğrusal bir yükseliş göstermemiştir. İlk anayasacllı hareketlerinden günümüze uzanan çetrefilli yolculukta anti demokratik 
müdahalelere ve kuvvetler birliği dönemlerine çokça rastlamak mümkündür. Uzun süre teokratik/teosantrik mutlak monarşi, bir dönemde de meşruti monarşi yönetim sistemi özellikleri gösteren Osmanlı Devleti'nde demokrasi veya kuvvetler ayrılığının (tarihsel gelişim izleri dişında) modern anlamda yansımalarını aramak anlamlı olmayacaktır Cumhuriyeti kuran iradenin anayasal demokrasi idealinin ne derece gerçekleștiği 1923 sonrası dönemin incelenmesini gerekli kılmaktadır (Çınar, 2017). Bu nedenle izleyen paragraflarda Cumhuriyet Dönemi yargı siyaset ilişkilerinin tarihsel seyri ele alınmıştır.

\section{Cumhuriyet Dönemi Yargı Siyaset İlişkilerinin Tarihsel Seyri}

1923-1950 arasındaki dönemde hukuk sistemi, esas olarak Batı hukuk sistemlerine öykünmek suretiyle yapılandırılmaya çalışılmıştır. Aslında Kıta Avrupa'sı hukukunun etkisi Tanzimat dönemine değin geriye götürülebilir. Genç Cumhuriyetin yöneticileri Rousseau'cu egemenlik anlayışını benimsediği için, mahkemelerin özellikle de siyasi iktidarla ilişkili yetkileri, sınırlandırılmaya çalışılmış ve ayrıca egemenliğin meclis elinde bulundurulmasına özen gösterilmiștir.

Yargı siyaset tartışmalarında, 'meclis hükümet modeli'nin uygulandığı, Cumhuriyetin ilk dönemlerinde kurulan, İstiklal Mahkemelerinin özel bir yeri vardır. Bu mahkemelerin ülkenin önemli bir bölümünün işgal altında olduğu harp şartlarında hızlı karar alınması ve uygulanması gerekliliği ile yeni kurulan ve Cumhuriyet rejiminin yerleștirilmesine yönelik siyasi korumacı nitelikleriyle ön plana çıktıkları söylenebilir (Aybars, 1975).

1950'de, güçlü bir ekseriyetle iktidarı ele alan Demokrat Parti (DP), toplumun demokrasi kültürünün ve deneyiminin sınırlı olmasının getirdiği siyasi çatışmalar girdabına düşmüş ve özellikle 1950 'lerin sonlarında ortaya koyduğu uygulama ve tutumları hak ve özgürlük bağlamında ciddi şekilde eleştirilere maruz kalmıștır. Toplumsal çatışmaların yükselmesi sonucu, Türkiye'de yasama ve yürütme organlarının anayasayı ihlal eden eylem ve ișlemlerine karşı ne tür tedbirler alınması gerektiği konusunu bir sorun alanı olarak ilk kez tartışmaya açılmıştır.

1924 Anayasası'nın yasama organını denetim altına alacak bir kuruma, dolayısıyla çoğulcu iktidarın anayasayı ihlal eden işlemlerine karşı müracaat edilebilecek hukuk yoluna yer vermemiş olması nedeniyle bu işlevin Yargıtay'ca yerine getirilmesi ve Yargitay'ın resen kendini görevlendirmesi gibi önermeler gündeme gelmiștir. Demokrasi içinde bir çıkış yolu arayan bu tartışmalar devam ederken 27 Mayıs 1960 günü askeri müdahale gelmiş ve askeri yönetim tarafından DP iktidarı sonlandırılmıștır (Toker, 1990).

Darbe ile 1924 Anayasası ve TBMM feshedilmiș, Milli Birlik Komitesi kurularak yeni bir anayasa hazırlanmıştır. Yeni Anayasa'nın genel felsefesine baktığımızda: kuvvetler ayrılığı ilkesinin benimsendiğini ve anayasal demokrasi için güçlü güvenceler getirdiğini muhtemelen 'Bir daha demokrasiden geri adım olmasın!' gibi bir anlayış ile yapıldığını gözlemlemek mümkündür. 1960 sonrasının en önemli ileri adımı ise Anayasa Mahkemesinin kurulmuş olmasıdır. H. Kelsen'in fikirlerinden izler taşıyan Anayasa Mahkemesi modeli, 1961 Anayasası'nı yazan hukukçular tarafından da benimsenmiştir (Kelsen, 2017). Bu suretle yasama fonksiyonunun faaliyetlerini denetleyen Anayasa Mahkemesi kurulmuş ve yargının görev alanı yeni bir ufuk kazanmıștır.

Türkiye'de yasama organının ve Cumhurbaşkanlığı Hükümet Sisteminin 'kural işlem' düzenlemelerini olușturan Cumhurbaşkanlığı Kararnamelerinin yargısal denetimini yapan tek organ Anayasa yargısıdır. Teoride anayasa mahkemelerinin işlevsel bir yönü, eksik demokrasilerin zaaflarından biri olarak kabul edilen 'çoğunluk despotizmi'nin engellemesidir. Anayasadan kaynağını alan bu yargısal yetki ile mahkemeler hukukun çizdiği sınırlar içinde siyasete müdahale edebilmektedirler. Bu 
güçlü yetkilendirmenin sınırı yine anayasa ile çizilmiștir ve mahkemeler anılan yetkiyi kullanırken demokrasinin evrensel gereklerine uygun davranmak yükümlülüğü altındadırlar.

Cumhuriyet tarihi boyunca, hemen her dönemde, Türkiye'de hukukun siyasallaştığına ilișkin iddialar öne sürülmüștür. Özellikle bu iddiaların ara rejim dönemlerinde, askeri müdahaleler ve olağanüstü hâl dönemlerinde sadır olan yargı kararları özelinde daha güçlü şekilde ifade edildiğini görmek mümkündür. Yassıda, 12 Mart, 12 Eylül ve son dönem Kumpas Davaları (Anayasa Mahkemesi, 2013/7800 sayılı kararında adil yargılanma hakkının ihlal edildiği hükme bağlanmıştır) hukukun siyasileștirilmesinin göze çarpan örneklerindendir. Bu mahkemeler olağan dönemlerde sanıklara çok daha güçlü yargısal güvenceler sağlayabilecek ve mahkûmiyetler için çok daha kapsamlı deliller arayabilecekken anılan ara dönemlerde yargısal güvencelerin ve gerekliliklerin çok daha azıyla yetinmişlerdir. Siyasi etki altındaki yargılamalar neticesinde birçok siyasi parti kapatılmıș, hürriyeti bağlayıcı cezalar verilmiş hatta pek çok siyasi kişi idam edilmiştir. Hukukun siyasileşmesinde, olağanüstü kurulan (ad hoc) mahkemeler, özel yetkili mahkemeler ve bazı uzmanlık mahkemeleri kuruluş yöntemleri ve yargılama usulleri bağlamında bu çerçevede ele alınabilecektir.

1961 Anayasası idarenin denetimi için yargıya ilkesel bir yetki tanımıştır. 1961 Anayasası hukuk devletini gerçekleștirebilmek için 'idarenin her türlü eylem ve işlemine karşı yargı yolunun açık olduğu'nu ifade etmiştir. 1982 Anayasası'nın aynı konuyu düzenleyen 125'nci Maddesi'nde ise bazı konularda yargı yolunu kapayan kurallar getirmiştir. Her ne kadar 2010 ve 2017 Anayasa değişiklikleri ile sınırlandırmalar kısmen daraltılmış ise de 1982 Anayasasının ilk șeklinde: Cumhurbaşkanı'nın tek bașına yapacağı işlemler hakkında, Yüksek Askerî Şûra kararları ile Hâkimler ve Savcılar Yüksek Kurulu kararlarına karşı yargı yoluna gidilemeyeceği anayasada açıkça düzenlenmiștir.

Anayasa Mahkemesinin yargl siyaset ilișkisinde 'kendine özgü' bir konumu bulunduğunu hatırlatmakta fayda bulunur. Anayasa Mahkemesi birçok davada hukuk kurallarını siyasi boyutlarıyla değerlendirmek zorunda kalmaktadır. Bunlardan birini siyasi parti kapatma davaları olușturmaktadır. $\mathrm{Bu}$ davalar Yargıtay Cumhuriyet Başsavcılığı tarafından açılabilmekte ve Anayasa Mahkemesi tarafından bakılmaktadır. Siyasi mülahazaların en üst seviyede olduğu parti kapatma davalarında mahkeme, anayasada düzenlenmiş olan hükümler ile birlikte 2820 sayılı Siyasi Partiler Kanunu'nun düzenlemelerine başvurmaktadır.

Ayrıca, her ne kadar 03.10.2001 tarihli ve 4709 sayılı Kanun'un çerçeve 34'üncü Maddesi'yle Anayasa Mahkemesi denetimini engelleyen son fikrası ilga edilmiş olsa da 1982 Anayasası'nın Geçici 15'inci maddesinin engel getirmesi nedeniyle darbenin yapıldığı 1980 yılı ile 1983 yılına kadar çıkarılan yasaların anayasaya aykırılığı uzun yıllar iddia edilememiştir.

\section{Anayasasında Kuvvetler Ayrılığı}

Kuvvetler ayrılığı ilkesi çağdaş devlet yapılanmalarının ve demokratik anayasaların temel bir değeridir. Kuvvetler ayrılığı ilkesi her türlü normatif düzenlemede dikkate alınması gereken bir öneme sahiptir. Örneğin, yargı gücünün bağımsız ve tarafsız olmasını zedeleyebilecek bir yasal düzenleme kuvvetler ayrılığını ihlal edeceği için Anayasa Mahkemesi tarafından iptal edilebilmeli ya da yürütmenin yetki alanını așarak yasamanın kural koyma işlevini gasp eden bir düzenleyici işlem yine kuvvetler ayrılığına aykırılık oluşturduğu gerekçesiyle normatif yönden denetlenebilmeli ve ortadan kaldırılabilmelidir. Birçok çağdaş Anayasa'da açılç̧a düzenlenmiş olan bu ilkeyi 1982 Anayasasında aynı açıklıkla göremiyoruz. 1982 Anayasası'nın Başlangıç Bölümünde: "Kuvvetler ayrımının, Devlet organları arasında üstünlük sıralaması anlamına gelmeyip, 
belli Devlet yetki ve görevlerinin kullanılmasından ibaret ve bununla sınırlı medenî bir iş bölümü ve iş birliği olduğu ve üstünlüğün ancak Anayasa ve kanunlarda bulunduğu..." (1982 Anayasası) belirtilmektedir. İlkenin dolaylı bir anlatımı ile kaleme alındığını söylemek olasıdır. Hatta Paragrafın hukuk felsefesi bağlamında değerlendirildiğinde, devlet fonksiyonları yönünden bir ayrımdan çok bütünselliğin arzuladığı sonucuna ulaşmak dahi mümkün görünmektedir. Bu düzenleme Anayasa Mahkemesinin bahse konu amaca ulaşabilmek için hukuki yorum metotlarında zorlama yapmasını gerekli kılmaktadır (Anayasa Mahkemesi, 2017/98).

Bir taraftan normatif düzenleme yetersizliği, diğer taraftan son derece 'disiplinli siyasi parti' yapılanmasına sahip siyaset kurumunun Türkiye'de tüm zeminleri kapsayıcı tutumu, yargı gücünün etkinliğine ve çalışma alanına olumsuz etki yapabilmektedir. Siyaset kurumuna bağlı çalışan idarenin yapmıș olduğu eylem ve işlemlerin sırasıyla ilk derece idare mahkemeleri, bölge idare mahkemeleri ve Danıștay tarafından; yasama organının çıkardığı normatif düzenlemelerin ise Anayasa Mahkemesi tarafından hukuksal denetiminin yapılabilmesi gerekmektedir. Ancak siyaset kurumunun yasama organında çoğunluğa sahip olması, yürütme organının da siyaset kurumu ile organik bağları bulunması yargının yasama ve yürütme organlarını gerektiği gibi denetleyemediği algısının yükselmesine buna paralel olarak yargıya duyulan güvenin azalmasına neden olmuştur. Yargıya duyulan güvenin tarihin en düşük seviyelerine indiği, yargının savunma ayağının en üst düzey temsilcisi Barolar Birliği Başkanı tarafından bizzat ifade edilmiștir (Feyzioğlu, 2017).

Yüzeysel bir bakış açısıyla anayasal çoğulcu demokrasinin temel asgari şartları sağlanıyor gibi görünse de yakından bakıldığında merkezinde Anayasa Mahkemesi, Yargıtay, Danıştay ve Yüksek Seçim Kurulu gibi yüksek yargı kurumlarının kararlarının olduğu yoğun tartışma ve endişeler yüksek sesle dile getirilmektedir. Devletin taraf olduğu ihtilaflarda yüksek yargı kurumlarının tercihlerini genel olarak devletten yana koydukları, özgürlükleri sınırlandıran yorumlar yaptıkları yolunda yakınmaların yanı sıra söz konusu yargı kurumlarının siyasi etki ve mülahazalarla güvenliği ve rejimi tehlikeye atan kararlar verdiğine dair de yorumlarla da karşılașılabilmektedir (Gözler, 2017 ve Şen, 2015).

Konuya ilişkin yakın zamanlı örneklerden biri de şudur: Anayasa Mahkemesinin daha önce OHAL ilanının gerekli kıldığı konuya ilișkin olmayan veya olağanüstü hâlin geçerli olduğu yer ve/veya dönem hâricinde yürürlükte olacak düzenlemeleri, OHAL KHK'sı niteliğinde görmeyerek bunların olağan dönem kanun hükmünde kararnameleri olduğunu kabul ederek yargı denetimine dâhil etmiștir. 15 Temmuz 2016 darbe girișimi sonrasında ise ilan edilen olağanüstü hâl döneminden bu görüșünden vazgeçerek OHAL KHK'larını denetlemekten tümden vaz geçmiştir (Resmi Gazete, sayı 29878). Bir diğeri, YSK'nın daha önceki içtihatlarına aykırı olarak 16 Nisan 2017 Anayasa Değişikliği Referandumu devam ettiği esnada 'mühürsüz oy zarflarının geçerli kabul edilmesi' konusunda verdiği karardır (YSK, 2017). Keza Anayasa Mahkemesinin daha önce yaptığı laik devlet yapısına ilişkin yorumlar ile tezat teşkil eden ve din görevlilerinin din işleri dışında kamusal görevler almalarını uygun gören 'müftülerin evlendirme göreviyle yetkilendirilmelerini' anayasa aykırı görmeyen kararı (Resmî Gazete, Sayı 30664) da bu kapsamdadır. Anayasa Mahkemesinin kararlarının tam olarak uygulanmamasına dair örnekler, yargının bağımsızlığı ve tarafsızlığı ile siyasetin yargıyı etkilemesi meselesini gündemin üst sıralarına taşımaktadır.

\section{Yargının Bağımsızlığı/Tarafsızlığı Meselesi}

Yargı bağımsızlığı yargı mensuplarına sağlanan bir ayrıcalık değil, yargıdan adil karar bekleyen kişiler için bir güvence olușturmaya yönelik düzenlemeler bütünüdür. 
Yargı bağımsızlığına ilişkin en geniş tabanlı çalışma Birleşmiş Milletler Örgütü (BM) tarafından yapılmıştır. Bu nedenle tüm BM'ye üye devletler yönünden uyulması gereken prensipler olarak önem arz etmektedir. Birleşmiş Milletler Genel Kurulu, Yargı Bağımsızlığının Temel IIlkeleri (The United Nations Basic Principles on the Independence of the Judiciary) başlığı altında, 13 Aralık 1985 tarihinde 40/146 sayılı kararıyla önemli bir düzenlemeyi kabul etmiştir (BM, 1985). BM'nin benimsediği ilkeler ile Türkiye yargısının mevcut durumu karşılaştırıldığında bazı eleştiri alanlarına kapı aralayacağına kuşku yoktur. Örnek olarak aşağıdaki prensipler yönünden düzenlemelerin yeterliliği ve doğru uygulamalar yapılmakta olduğu tartışmaya açıktır:

Yargı organı önündeki sorun hakkında doğrudan veya dolaylı kısıtlama, etki, teşvik, baskı, tehdit ve müdahaleye maruz kalmaksızın, maddi olaylara ve hukuka dayanarak tarafsız bir biçimde karar verir.

Yargılama sürecine usulsüz ve yetkisiz müdahale yapılamaz ve yargısal kararlar değișikliğe tabi tutulamaz.

Hâkimler, gerekli hukuk eğitimini almıș, dürüst ve ehliyetli kișiler arasından seçilir. Yargı görevlerine getirilme yöntemleri düzenlenirken, yargı dışı etkenler ile atama yapılmasına karşı koruyucu tedbirler getirilir. Hâkimlerin seçiminde ırk, renk, cinsiyet, din, siyasal veya başka bir fikir, ulusal veya toplumsal köken, mülkiyet, doğum ve toplumsal statü benzeri sebeplerle hiç kimseye yönelik ayrımcılık yapılamaz.

Hâkimlerin yükselmelerinde liyakat sistemi esas alınır.

Hâkimler yalnızca görevlerini yapamayacak duruma gelmeleri veya görevleriyle bağdaşmayacak davranıșlarda bulunmaları sebebiyle görevlerinden alınabilir tabidir.

Disiplin, uzaklaștırma ve göreve son verme kararları bağımsız bir denetime

Yargı bağımsızlı̆̆ı yönünden birçok sorun alanı bulunduğu söylenebilir ancak iki temel eleştiri noktasının özellikle altını çizmek gerekir. Bunların ilki; Anayasa Mahkemesinin teşkil edilme biçiminde siyaset kurumunun doğrudan etkisi, ikincisi ise Hâkim ve Savcılar Kurulunun (HSK) teşkilat yapısında siyaset kurumunun başkan ve başkan yardımcısı seviyesinde konumlanmış olmasıdır. Anayasa Mahkemesi, anayasa değişikliklerinin, kanunların anayasaya aykırılıklarını denetleyen, siyasi partilerin kapatılmasından, milletvekilliklerinin düşürülmesine değin geniş bir görev alanında faaliyet gösteren ayrıca Cumhurbaşkanı ve üst düzey devlet yetkililerini Yüce Divan sıfatıyla yargllama yetkisine sahip bir mahkemedir. Ancak Mahkemenin kuruluşunda özellikle 2010 ve 2017 Anayasa değişiklikleri sonrasında siyaset kurumunun güçlü etkisi gözlerden kaçmamaktadır. 15 üyeli mahkemenin 12 üyesini hiçbir objektif kritere ve denetime tabi olmaksızın (bir siyasi partinin lideri olmasında anayasal bir engel bulunmayan) Cumhurbaşkanı seçmektedir. Geri kalan üç üye ise yine siyaset kurumunun etkin olduğu yasama organı tarafından seçilmektedir.

Diğer taraftan yargı bağımsızlığının en temel kurumlarından biri olan Hâkim ve Savcılar Kurulu (HSK- 2017 değişiklikleri öncesi adı Hâkim ve Savcılar Yüksek Kurulu idi) 13 üyeden oluşmaktadır. Hâkim ve savcıların mesleğe alınmaları, atanmaları, yüksek mahkemelere seçilmeleri, disiplin işlemleri ve meslekten çıkarılmaları gibi son derece önemli görevleri yerine getirmektedir. Bu yapıda da siyaset kurumunun güçlü etkisini görüyoruz. Kurulun Başkanı Adalet Bakanı olup Adalet Bakanlığının bir Bakan Yardımcısı Kurulun tabiî üyesidir. Kurulun, üç üyesi Cumhurbaşkanı tarafından; üç üyesi Yargıtay üyelerince, bir üyesi Danıştay üyeleri tarafından, üç üyesi yükseköğretim kurumlarının hukuk dallarında görev yapan öğretim üyeleri ile avukatlar arasından Türkiye Büyük Millet Meclisi Genel Kurulunca seçilmektedir. Cumhurbaşkanlığı sisteminin bir gereği olarak (halen bir siyasi partinin başkanı olan) Cumhurbaşkanının talimatlarına tabi olarak çalışmak zorunda olan Adalet bakanı ve onun yardımcısı kurulun tabii üyeleridir. Bunun yanı sıra hiçbir objektif kritere ve denetime tabi olmaksızın Cumhurbaşkanı dört 
üye daha seçebilmektedir. Bunlara ek olarak tamamen siyaset kurumunun (halen Cumhurbaşkanının başkanlığını yaptığı siyasi partinin çoğunlukta olduğu) TBMM tarafından 7 üye daha seçilmektedir. Bu tablo, yargının siyaset kurumunun etkisine alabildiğince maruz kaldığı eleștirilerine kapıları sonuna kadar açmaktadır.

Yargı bağımsızlığının aslî gerekçesi yargı organlarının, vazifelerini yerine getirirken iktidar odaklarının yapabileceği müdahalelerden korunaklı olmalarının temin edilmesidir. Bu anlayış anayasal çoğulcu demokratik devlet öngörüsünün önemli bir zirve noktasıdır. Hâkimler dışsal etki veya baskıya karşı korunmadıkları sürece, adalete ve hukuka uygun olarak tarafsız şekilde karar verebilecek zihinsel bir huzur içinde olamazlar. Hâkimin kararlarının efendisi hukuk ve vicdanı olmalıdır. Yargı bağımsızlığı bireysel özgürlüklerin en büyük güvencesidir. Yargı bağımsızlığı bu yönüyle adaletin sağlanmasına hizmet etmektedir. Bu tür devletlerde hâkimlerin siyasal tarafsızlığa kesin olarak riayet etmeleri beklenir. Hukukun otoritesini yașatabilmesi onların siyasallaşmamasına bağlıdır. Siyasallaşan hâkimlerin bağımsız ve tarafsız olmaları da doğal olarak mümkün olamayacaktır.

Hâkimlerin tarafsızlığı salt davacı ve davalı yönünden yan tutmama şeklindeki davranışsal bir tarafsızlık olarak algılanma eğilimi oldukça yüksektir. Oysa yargının devlete, iktidara, hükümete ve sair iktidar odaklarına karşı da tarafsız olması en az davanın taraflarına karşı yan tutmama eğilimi kadar önemli ve gereklidir. Yargı mensuplarının siyasetten etkilenmeleri çeşitli şekilde ortaya çıkabilmektedir. Bunlardan biri hükümet, meclis, milletvekili gibi siyasi kurumların yargı üzerinde muhtelif etkiler yapmalarının sonucu ortaya çıkabilir. Bu etki yargının siyasi iktidardan bağımsız olmasını sağlayan kurumsal yapılanmalar ve hukuksal düzenlemeler yoluyla bir ölçüde önlenmesi mümkün olabilir. Bir diğer etkilenme süreci ise bizatihi yargı mensuplarının aşiret, cemaat, eğitim, din gibi etki ve ön yargılarından kaynağını alan ve bu etkilerin karar verme sürecine yön vermesiyle neticelenen etkilenme süreci olarak karışımıza çıkabilmektedir. $\mathrm{Bu}$ ise yargı mensuplarının nasıl seçildikleri, atandıkları, denetlendikleri, terfi ettikleri ve ödüllendirildikleri gibi çok boyutlu düzenlemeler ve düzeltmeler ile ilgili görünmektedir.

Bazı hâkimlerin kendilerini, Türk Milleti adına yargı yetkisini kullanan bağımsız otoriteler olarak değil de farklı hiyerarşik yapıların örneğin bir cemaatin, bir siyasal düşüncenin mensubu hatta muhafızı olarak gördükleri örnekler mevcuttur. Bazı dönemlerde evrensel hukuk ilke ve tekniklerine aykırı olarak düzenlenmiş, bundan da öte bir ideolojinin veya inancın tebliğine benzeyen iddianamelere ve yargı kararlarına rastlandığı olmuștur. Toplum gündeminde yer alan bazı davalarla (örneğin FETÖ'nün kurguladığı kumpas yarglamalarıyla) ilgili olarak kamuoyu yoklamalarında davaların siyasi olduğuna dair kanaatlerin son derece yüksek olduğu gözlemlenmiştir (Barolar Birliği, 2016).

Yukarıdaki veriler ışığında, yargının ana işlevleri ve tarafsızlığı konusu ülkemiz açısından hayli önemli bir sorun alanını oluşturduğu inkâr edilemez bir gerçekliktir. Yargının temel fonksiyonu tarafsız olarak adaletin ne olduğunu söylemektir. Avrupa Komisyonu ile Liberal Düşünce Topluluğu'nun birlikte gerçekleştirdiği bir çalışma bu konuda bize dikkate değer veriler sunmaktadır. Bu araştırmada deneklere yöneltilen 'Türkiye'de mahkemeler, kanunları adil ve tarafsız olarak uyguluyor mu?' sualine, ankete dâhil olanların \% 64,5'i olumsuz, \% 21,2'i olumlu cevap vermişlerdir. Düșüncesini açıklamayanların oranı \% 14,3 olarak gerçekleşmiştir. Ankete göre toplumun 1/5'i yargı kararlarını tarafsız ve adil bulmakta, buna karşılık büyük çoğunluğu olușturan 3/5'lik kitle ise yargı kararlarını tarafsız ve adalete uygun görmemektedir. Cevap vermekten kaçınan önemli bir grubun ise kendilerini yeterli kamusal hak ve güvenceler içinde hissetmiyor olmaları kuvvetle muhtemel görünmektedir (Avrupa Komisyonu, 2003). Yargıya duyulan güvenin $\% 70$ 'ten $\% 30$ 'a indiği yine yargının en üst düzey 
temsilcilerinden biri olan Yargıtay Başkanı tarafından bizzat dile getirilmiştir (Cirit, 2018).

Türkiye'nin, geniş anlamıyla yargı konseptiyle ilgili sorun alanları ele alındığında, geniş bir yelpazede sorunların dağıldı̆̆ını görmek mümkündür (Erden, 2005). Yukarıdaki tüm açıklamalar ışığında sorun alanlarını sıralamak gerekirse aşağıdaki çıkarımlara ulaşlabilir.

Hukuk Fakülteleri sorunu: eğitimci, eğitim ve alt yapı yetersizlikleri,

Hâkimlik/savcıllk mesleğine ilk atama sorunu: çok genç yaşta ve yeterli bilgi ve tecrübeye sahip olmayan kişilerin mesleğe alınması; seçimde uygulanan sınavların tarafsızlığı ve yetkin kişileri belirlemede yetersizliği; alımların siyasi etkiden bağımsızlığı meselesi,

Hâkimlik/savcılık stajı sorunu; stajların teorik ve uygulama yönünden yetersizliği, farklı kaynaklardan gelen adaylara farklı süreler uygulanması; yargı bağımsızlığı ve tarafsızlığı ve mesleki etik değerlerinin kazandırılması meselesi,

Hâkim/savcı atamaları ile meslek içi yükselme sorunu: atama ve yükselmelerde adalet ve liyakat ilkelerinin tam olarak uygulanması ile siyasi etkinin ortadan kaldırılması meselesi,

Hâkim ve savcıların atama yeri ve görev noktası güvencelerinin yetersiz olması

Hâkimler ve Savcılar Kuruluna ilişkin sorunlar:

Siyaset kurumunun (Cumhurbaşkanlı̆̆ hükümet modeli olması nedeniyle yürütme organında yer alan ve yasama organı ile organik bağı bulunan) Adalet Bakanının HSK Başkanı olması; bunun yanı sıra aynı olumsuzluklarla gelen, Adalet Bakanlığı Bakan Yardımcısının Kurulun doğal üyesi olması meselesi,

Kurulun bağımsızlığını sağlayacak yeterli alt yapı ve mevzuatın bulunmaması,

Kurulunun üyelerinin belirlenmesinde siyaset kurumu (dolayısıyla yürütme ve yasama organının) son derece etkili olması,

Kurulun meslekten çıkarma cezaları hariç diğer kararlarının yargı denetimi dişında tutulmasi,

Siyaset kurumunun temsilcisi Adalet Bakanı/lığının yargı kuvveti üzerindeki güçlü etki ve yetkileri:

Adliye teşkilatında kuruluş oluşturma ve değiştirme yetkisi ile personel görevlendirme yetkisinin Bakanlığına ait olması;

Hâkim/savcı özlük işlerini takip eden Personel Genel Müdürlüğü'nün Adalet Bakanlığı teşkilatında olması;

2802 s. Hâkim ve Savcllar Kanununun “Gözetim ve Denetim Hakkı" bașlıklı 5'nci maddesinin, Adalet Bakanına hâkim ve savcılar üzerinde gözetim hakkı verilmiş olması ve idari görevler yönünden hâkim/savcıların Adalet Bakanlığına bağlı kılınmış olmaları;

Hâkim ve savcılar hakkındaki soruşturma yapma yetkisinin Adalet Bakanına ait olması ve Adalet Bakanına bağlı müfettişler tarafından yerine getirilmesi ve

Yargı örgütü için bütçeden ayrılan payın düşük olması ve Adalet Bakanlığı üzerinden yürürlüğe koyulması.

Montesquieu kitabını yazdığı dönemde "üç yetkinin padişahın kişiliğinde birleşmiş olduğundan Türkiye'de korkunç bir istibdat idaresi bulunduğunu" (Montesquieu, 1963) ifade etmektedir. Türk Anayasasında yargı ayrı bir kuvvet olarak düzenlenmiş ve çeşitli güvencelerle koruma altına alınmış ise de yukarıda sayılan sorun alanları, kuvvetler ayrılığının yeterince uygulama alanı bulamadığını ve beklenen seviyede bir yargı bağımsızlığına henüz erişilemediğini göstermektedir. Montesquieu'nün belirttiği kadar vahim olmasa da, onun ruhunun hala mutlu olmadığın gösteren kanıtlar var gibi görünmektedir. 


\section{Sonuç ve Değerlendirme}

Çağdaş demokrasiler ancak hukuk devleti temelinde yaşayabilirler. Hukuk devletini; insan haklarına dayanan, birey hak ve özgürlüklerini genişleten; adaletli bir hukuk sistemi kuran ve işleten; hukukun genel ilkelerine ve anayasaya aykırı tutumlardan kaçınan; eylem ve işlemleri hukuka uygun olan; yargı denetimine açık ve yargı kararlarına uyan devlet olarak betimlemek mümkündür.

Kuvvetler ayrılı̆̆ ilkesinin temelinde kuvvetlerin bir diğerinin görev ve yetki alanlarına müdahale etmeksizin kendi özerk alanlarında fonksiyonlarını yerine getirebilmeleri düşüncesi yatmaktadır. Bir başka deyişle bu ilke; yasama, yürütme ve yargı organlarının birbirinin işlevine karışmaksızın kendi çalışmalarını yönetebilmesi olanağı şeklinde de ifade edilebilir. Kuvvetler ayrılığı ile hukuk devleti kavramlarının ortak kesișim noktalarından biri 'Yargı Bağımsızlığı ve Tarafsızlı̆̆ı' ilkesi olarak karșımıza çıkmaktadır. Literatürde 'Yargl/Yargıç/Mahkemelerin-Bağımsızlığı/Tarafsızlığı' șeklinde ifade edilen bu konseptin pratiğini siyaset ile yargı ilişkilerinde belirleyici etki yapmasında görmekteyiz. Şayet yargı bağımsızlığını sağlayan teminatlar yeterli ise hukuk devleti ve kuvvetler ayrıllğı hayata geçirilebilmekte bu teminatlar yetersiz ise yargı siyaset denklemi eșitlik değil, negatif sonuç vermektedir.

Tarihsel tecrübe, otoriterliğe dönüșme yönünden en tehlikeli siyasal sistemin, yürütmenin yetkilerin çoğunu eline geçirdiği, yasamanın yürütmeye tabi olduğu ve onu denetleyemediği, yargının ise etkinliğinin kırıldığı sistemler olduğunu göstermektedir. Fransa 1799, Fransa 1848, Almanya 1933 Anayasaları ile yürürlüğe koyulmuş olan bu sistemler ve birçok Afrika ve Latin Amerika deneyimleri kısa bir süre sonra diktatörlüğe evirilmiştir. Bu sistemlerde, güç odağı haline gelen yürütme diğer tüm güçler karşısında kedisini devleti temsil eden tek yetkili makam olarak algılamaya başlamaktadır. Yürütmenin başının, devletin üst düzey görevlilerini belirleme yetkisi bulunması, hükûmetin güvenoyuna ihtiyaç duymaksızın göreve başlayabiliyor ve devam edebiliyor olması, meclisi fesih yetkisi ile tüm kabineyi değiștirme olanakları, milli egemenlik yetkisinin tek elde toplanmasının en güçlü tezahür biçimleridir.

Yürütmenin dayandığı siyasi parti üzerindeki hâkimiyetinin devam ettiği durumlarda, parti teşkilatı üzerinden ülkenin en uç noktalarına değin etkin ve belirleyici olma kudreti ters açıdan bakıldığında da ülkenin en uç noktasındaki siyasilerin üst düzey yöneticileri etkileyebilmektedir. Böyle bir yapı ise kolaylıkla otoriter bir yönetim şekline evirilebilmektedir. Ayrıca, devlet sisteminin kapsayıcı bir siyasi parti egemenliği altında, yürütme-yasama döngüsüne girmesi, yargının da bu girdaba kapılmasını kaçınılmaz kılmaktadır.

Bağımsızlık ve tarafsızlık iktidar sahibi olmayı ve toplumsal iktidar odaklarının etkisinden masun olmayı gerektirir. Bu bağlamda asıl mesele yargının sahip olması gereken yetkiler siyaset kurumu tarafından tırpanlanırsa yargıdan geriye neyin kalacağı dramatik sorusudur.

\section{KAYNAKÇA}

ABD Anayasası (The Constitution), Erişim Tarihi: 18.03.2019, https://www.archives.gov/founding-docs/constitution-transcript

ARISTOTELES. (1975). Politika, 1.Basım, (M. Tuncay Çev.), İstanbul: Remzi Yayınevi. 

Matbaasl.

ARSEL, İ. (1968). Anayasa Hukuku (Demokrasi). (2. Baskı). İstanbul: Surlar

ARSLAN Z. (Ekim, 2013). Sened-i İttifak'ın ortaya çıkıșı ve insan hakları bakımından değerlendirilmesi; Emergence of Charter of Alliance and evaluation from the aspect of human rights. International Journal of Social Science, C 6. 77-91, doi: dx.doi.org/10.9761/JASSS1971

Avrupa Komisyonu \& Liberal Düşünce Topluluğu (2003). Türkiye'de insan hakları ve ifade özgürlüğü istatistiği. Yargıya duyulan güven bölümü. Erişim tarihi:21.03.2019,

http://www.liberal.org.tr/upresimler/insan haklari ifade ozgurlugu 24.pdf

AYBARS E. (1975). İstiklal Mahkemeleri, Ankara: Bilgi Yayınevi.

Barolar Birliği (2016). Türkiye'de siyasal davalarda avukatlık paneli. Erişim tarihi: 09.05.2016, https://www.barobirlik.org.tr/Haberler/-siyasi-davalardaavukatlik--69848

Birleșmiș Milletler. Yargı bağımsızlığının temel ilkeleri. Erișim tarihi:31.03.2019, https://www.ohchr.org/EN/ProfessionalInterest/Pages/IndependenceJudiciary.aspx

CİRIT, İ.R. (2018) Uluslararası Arabuluculuk Sempozyumu. Yargıtay Başkanından yargıya duyulan güven \%30'lara düştü açıklaması. Erişim tarihi:31.03.2019, http://www.milliyet.com.tr/-yargiya-guven-yuzde-30-a-dustu--gundem-2236520

ÇINAR M.F. (2017, Aralık). Türkiye'nin anayasal demokrasi yolu ve kuvvetler ayrılığı ilkesinin serencamı. Uluslararası Hakemli Akademik Bakış Dergisi, Sayı 64, 586607. Erişim tarihi: 22.01.2019, http://dergipark.gov.tr/download/article-file/438447

ÇINAR M.F. (2018). Hükümet sistemlerinin tarihsel gelişimleri ışığında Türkiye için anayasal önermeler (Yayınlanmamıș Doktora Tezi), Dokuz Eylül Üniversitesi, İzmir.

DOEHRING K. (2002). Genel Devlet Kuramı-Genel Kamu Hukuku. (Mumcu A. Çev.), (4.Baskı). İstanbul: İnkılâp Yayınevi Yayınları

DUVERGER M. (1995). Siyaset Sosyolojisi, (Ș. Tekeli Çev.), İstanbul: Varlık

ELECHES C. P., PORTA R.L. SHLEIFER, A. SILANES F.L.D. (2004). Judicial Checks and Balances, Journal of Political Economy. (vol.112), (no.2), Erişim tarihi: 24.03.2019, http://www.columbia.edu/ cp2124/papers/popeleches judicial.pdf

ERDEN, F.H. (2005): Türkiye'de ideolojik devlet gölgesinde yargı ve bağımsızlı̆̆ sorunu, Ankara: Demokrasi Platformu Dergisi, S 2.

FEYZİOĞLU M. (2017) Barolar Birliği adlı yıl açılış konuşması (Yargıya duyulan güvenin azaldığı açılklaması). Erişim tarihi 31.03.2019, https://goo.gl/ijyZp2

GÖZLER, K. (2011). Anayasa hukuku genel teorisi (cilt I), Bursa: Ekin Basımevi.

GÖZLER, K. (2017). Elveda anayasa 16 Nisan 2017'de oylayacağımız anayasa değişikliği hakkında eleștiriler, Bursa: Ekin Kitapevi.

HAMILTON A. (1788). The Federalist Papers: No.78, The Judiciary Department,

Erişim tarihi: 15.03.2019, http://avalon.law.yale.edu/18th century/fed78.asp

HOBBES, T. (2007). Leviathan veya Bir Din ve Dünya Devletinin İçeriği, Biçimi ve

Kudreti. (S. Lim, Çev.), 6.Baskı, İstanbul: Yapı Kredi Yayınları.

İSTTEN İ. (2014). Yargı bağımsızlığı ve tarafsızlığı. Gaziantep Üniversitesi Journal of

Social Sciences Dergisi, Sayı 13(2). Erișim tarihi: 26.03.2019, http://jss.gantep.edu.tr

KAPANI, M. (2007). Politika Bilimine Giriş. (19.Baskı), Ankara: Bilgi Yayınevi.

KARAHANOĞULLARI O. (2005). Türkiye'de İdari Yargı Tarihi. Ankara: Turhan

Kitabevi.

KELSEN H. (2017). General theory of law \& state, (A.J. Trevino Ed.), New York:

Taylor \& Francis Group Routledge

LOCKE J. (2002). Sivil Toplumda, Devlet, Uygar Yönetim Üzerine Íkinci İnceleme.

(S. Taşçc; H. Akman Çev.), İstanbul: Metropol Yayınları. 
MONTESQUIEU. (1963). De L'Esprit des Lois (Kanunların Ruhu Üzerine), (cilt I). Dünya Edebiyatından Tercümeler Fransız Klasikleri, (F. Baldaş Çev.) Ankara: M.E. B. Basımevi.

ÜÇOK C., MUMCU A. (1991). Türk hukuk tarihi. Ankara: Savaş Yayınları.

PACTEAU, B. (1997). Fransız Danıştayı (Conseil D’Etat). (D. Tezcan Çev.), Erișim tarihi: 29.03.2019, http://dergiler.ankara.edu.tr/dergiler/42/480/5593.pdf Yayınları.

PLATON. (2005). Devlet, (C. Saraçoğlu; V. Ataman Çev.), İstanbul: Bordo Siyah

Resmî Gazete. 5 Temmuz 2014 tarihli ve sayı 29051. Anayasa Mahkemesinin Fetullahçı terör örgütü hâkimleri tarafından yargılanarak müebbet hapis cezaları dâhil olmak üzere cezalandırılan 230 kişinin başvurusu konusunda adil yargılama hakkının ihlal edildiğine dair 2013/7800 Başvuru Numaralı 18.06.2014 tarihli kararı. Erișim tarihi: 25.03.2019, http://www.resmigazete.gov.tr/eskiler/2014/07/20140705.htm

Resmî Gazete. 5 Temmuz 2014 tarihli ve sayı 29051. Anayasa Mahkemesinin demokrasi tanımı içeren 2014/256 Başvuru Numaralı 25.06.2014 tarihli kararı. Erişim tarihi: 25.03.2019, http://www.resmigazete.gov.tr/eskiler/2014/07/20140705.htm

Resmî Gazete. 4 Kasım 2016 tarihli ve sayı 29878. Anayasa Mahkemesinin önceki içtihatlarından ayrılarak, OHAL KHK'larının yargısal denetimini yapmaktan vazgeçtiğine dair 2016/166-159 E.K. sayılı 12.10.2016 tarihli kararı. Erişim tarihi:31.03.2019, http://www.resmigazete.gov.tr/eskiler/2016/11/20161104-4.pdf

Resmî Gazete. 3 Ağustos 2017 tarihli ve sayı 30143. Anayasa Mahkemesinin kuvvetler ayrılığını irdelediği 4.5.2017 tarihli ve 2015/41-2017/98 E.K. sayılı kararı. Erişim tarihi: 29.03.2019, http://www.resmigazete.gov.tr/eskiler/2017/08/201708039.pdf

Resmî Gazete. 23 Ocak 2019 tarih ve sayı 30664. Anayasa Mahkemesinin 06.12.2018 tarih ve 2017/180-2018/109 E.K. sayılı, müftülüklere evlendirme yetkisi tanımanın anayasaya aykırı olmadığı kararı. Erișim tarihi:31.032019,

http://www.resmigazete.gov.tr/eskiler/2019/01/20190123-7.pdf

ŞEN, E. (2015). Özgür yargı. Erişim tarihi:31.03.2019, http://sen.av.tr/tr/makaledetay/113/özgür_yargı.html

TOKER M. (1990). Tek partiden çok partiye 1944-1950 (Demokrasimizin İsmet Paşalı yılları 1944-1973). Ankara: Bilgi Yayınevi.

Türk Anayasaları. Erişim tarihi: 28.03.2019, https://anayasa.tbmm.gov.tr

Türk Dil Kurumu. (2019) Türkçe sözlük. Erişim tarihi: 18.03.2019, http://www.tdk.gov.tr/index.php?option=com bts\&arama=kelime\&guid=TDK.GTS.5c9d 0954627073.91704762

Yüksek Seçim Kurulunun 16 Nisan 2017 tarih ve Karar No:560 kararı. Erişim tarihi 24.01.2019, http://www.ysk.gov.tr/doc/karar/dosya/5059/2017-560.pdf

\section{Summary}

The aim of this study is to analyze the relationship between the politics and the judiciary as well as how the concept of judicial independence and impartiality are shaped within the framework of this relationship from the perspective of separation of power in Turkey. Today the allegations related to the distinction between politics and the judiciary are becoming more indistinct in Turkey are increasing. These claims focus on the point that relations between the politics and the judiciary deviate from the point at which they should be and require the legal values of the principle of separation of powers to be examined in terms of national and international judicial regulations related to the judicial independence. 
The study is a qualitative and descriptive research. The study data were obtained through the analysis of secondary sources-literature scan (Constitutional Court Decisions, Official Gazette archives, relevant legislation, related literature, newspaper archives, statistical data of the relevant researches) and subjected to an analytical evaluation.

Two serious problem may arise when entered a path outside the separation of powers in terms of the relations between the judiciary and the political of. The first is the danger of losing the credibility of the politicized judiciary and the second is the question of the judicialization of politics which emerged by the intervention of the judiciary in the politics. In both cases, the function of protecting the freedoms by controlling the political power cannot fulfill by the judiciary and the functional legitimacy crisis may arise.

We do not see this principle which is clearly defined in many modern constitutions in the 1982 Constitution. It is possible to say that the principle was written with an indirect narrative. Even in the context of the legal philosophy of the Paragraph, it is even possible to conclude that there is a desire for totality rather than a distinction in terms of state functions. However, it is positive that the Constitutional Court accepts the existence of the principle and cites it in its decisions.

The lack of normative acts on the one hand and the inclusive attitude of the embodiment of a highly disciplined political party with political institutions in Turkey on the other hand, adversely affect the efficiency and the work area of the judicial power. The President of the Union of Bar Associations, who is the highest representative of the Court of Appeal and the highest representatives of the judiciary (highest representative of the defense leg) expressed that the trust in the judiciary is at its lowest level in Turkey.

One of the common points of intersection between the separation of power and the concepts of the rule of law is the principle of independence and neutrality of the judiciary. We see the practice of the concept of judicial independence as decisive in the relations between the politics and the judiciary. If the guarantees providing for the independence of the judiciary are sufficient, the rule of law and the separation of powers can be realized and if these guarantees are insufficient, the equation of judicial versus politics does not result in equality but gives negative results.

Historical experience shows that the most dangerous political system in terms of transformation into authoritarianism is the one that the executive has taken over most of the powers and, the legislature it cannot control it (subject to enforcement) and thus, the judiciary is ineffective. In these systems, the force that becomes a focus of power begins to perceive itself as the only competent authority that represents the state against all other powers. The head of the executive is the strongest manifestation of the power of national sovereignty, with the authority to determine the top officials of the state. In such a case the government and has the ability to change the whole cabinet without the need for confidence, with the power of annulment. In some instances, when the dominance of the executive on the political party on which it is based continues in a disciplined manner, party organization can influence senior managers. In such a case the state system enters into an executivelegislative cycle under the rule of an overarching political party and it makes inevitable for the judiciary to drawn into this vortex and such a structure can be transformed into an authoritarian regime.

Independence and impartiality require to have power and to be free from the influence of the focus of social power. In this context, the main question which is the most dramatic one of what will be left of the judiciary if the powers that the judiciary should have are being scrapped by the political institution. 